\title{
Using stated preference valuation in the offshore environment to support marine planning
}

Tobias Börger ${ }^{\mathrm{a}}$, Tara L. Hooper ${ }^{\mathrm{b}}$, Melanie C. Austen ${ }^{\mathrm{b}}$, Oceane Marcone ${ }^{\mathrm{b}}$, Olivia Rendón ${ }^{\mathrm{b}}$

\author{
a University of Stirling, Economics Division, Stirling FK9 4LA, UK \\ ${ }^{b}$ Plymouth Marine Laboratory, Prospect Place, The Hoe, Plymouth PL1 3DH, UK
}

Abstract: This study presents valuations of components of marine natural capital that have hitherto been overlooked by the valuation literature. Using a discrete choice experiment, it values a set of ecosystem services linked to seabed natural capital in the UK section of the North Sea. The study focuses on offshore seabed habitats, using Good Environmental Status as a measure of seabed health, thus linking directly to management targets under the EU Marine Strategy Framework Directive. It considers how changing pressures on seabed habitats could affect marine industries and other ecosystems through trade-offs with (1) the contribution that exploitation of these habitats makes to the maritime cultural heritage; and (2) changes to the health of seabird populations. For seabed habitats and seabirds, the elicited values mainly represent non-use values for changes in the condition of natural capital assets. For maritime cultural heritage the valuation refers to the changed provision of this cultural ecosystem service. Results show that the public in England hold significant, strongly correlated, values for changes in the condition of offshore seabeds and seabird populations. Projected losses in maritime cultural heritage are found to lead to expected welfare decreases. Implications of these findings for marine planning and decision-making are discussed. 
Keywords: Marine planning, marine natural capital, marine ecosystem services, discrete choice experiments, stated preferences

\section{Introduction}

The valuation, accounting and management of natural capital and ecosystem services has recently gained a lot of attention in academic and policy circles alike (Austen et al. 2019). The European Union (EU) established a Working Group on Mapping and Assessment of Ecosystems and their Services (MAES; Maes et al. 2013) and more recently the Knowledge Implementation Project on the Integrated system for Natural Capital and ecosystem services Accounting (KIP-INCA; European Commission \& European Environment Agency 2016). The United Kingdom is among the countries at the forefront of the development of a natural capital approach and its application to policy, having commissioned the first national-scale assessment of ecosystem services and benefits with the UK National Ecosystem Assessment (NEA-FO 2014, NEA 2011). Almost simultaneously and aligning with the EU's Biodiversity Strategy (2011), the UK Government also published an Environment White Paper in 2011 (HM Government 2011) which committed it to include natural capital within the Environmental Accounts in the UK and to establish a Natural Capital Committee as an advisory body. This focus on the natural capital approach has continued with the recent publication of the government's 25 Year Environment Plan (HM Government 2018). Application within the marine environment has tended to advance more slowly, although there are examples of recent progress in this field including that commissioned by the Department for the Environment Food and Rural Affairs and by Scottish Natural Heritage to improve efforts to operationalise the natural capital approach for coastal and marine areas (Hooper et al. 2019a, Tillin et al. 2019).

The application of the natural capital approach to the marine environment implies a focus on the valuation of the goods and services that it provides. The valuation of marine goods and services and thereby marine natural capital is important for a number of reasons. Whenever the condition of marine natural capital is affected by environmental management measures, this has implications for its value. Valuation can highlight trade-offs between different uses of the marine environment, such as fishing, recreation, energy generation, conservation and shipping (Austen et al. 2019), which is why it has been argued it should be incorporated into marine spatial planning (Börger et al. 2014a). In this way, economic valuation of marine natural capital can support decision-making through providing information on costs, benefits and trade-offs (Torres and Hanley 2017) and help justify investment decisions (Natural Capital Committee 2015). Economic information also has the potential to inform the development of financial mechanisms for environmental management including payments for ecosystem services (Binet et al. 2013, Lau 2013). 
However, the valuation of natural capital and the goods and services it provides has focused mostly on terrestrial applications (Liquete et al. 2013, Maes et al. 2013). Classifications of ecosystem goods and services from the marine environment (e.g. Böhnke-Henrichs et al. 2013, Hattam et al. 2015) have lagged behind those more general classifications which mainly focused on terrestrial ecosystems (e.g. MEA 2005, TEEB 2010), although this has recently been addressed in version 5.1 of the CICES classification (Haines-Young and Potschin 2018). The same is true for valuation, where applications to marine areas have increased (Torres and Hanley 2016) but still continue to focus on those elements of marine systems with which people are most familiar. Most commonly valued are specific habitat types, such as wetlands, beaches, coral reefs (notable exceptions are reviewed in Section 2), and a limited set of services, particularly recreation, fisheries, carbon sequestration and water quality (Hooper et al. 2019a, Sagebiel et al. 2016, Torres and Hanley 2016). There is a need for the substantial gaps in valuations of marine ecosystem services to be filled, particularly in the context of marine planning and management (Bertram et al. 2014).

Valuation of marine natural capital differs from terrestrial applications in a number of ways. Respondents in survey-based approaches are often less familiar with marine ecosystems, which they might perceive as remote and complex (Jefferson et al. 2014, Rose et al. 2008, Steel et al. 2005). In the vast majority of cases, marine natural capital assets are spatially removed from the individuals, communities and industrial sectors that derive value from them. Consequently, there is little engagement and experience of the general public with offshore marine natural capital, which in turn adds to the perception of remoteness, unfamiliarity and complexity. Marine ecosystems are characterised by a much higher degree of interconnectedness and mobility compared to most terrestrial ecosystems. This makes the description and delineation of the impact of specific management measures on natural capital assets particularly challenging. This challenge carries over into the development of survey instruments for stated preference valuation.

Given the increased focus of environmental management on the marine environment through marine (spatial) planning (Douvere 2008, Douvere and Ehler 2009) and the development of plans for a blue economy in many countries (Austen et al. 2019, Spalding 2016), there is an ever growing demand for the valuation of marine natural capital. Against this background, the present study presents a stated preference valuation study of a set of ecosystem services linked to subtidal sedimentary seabed, an example of offshore marine natural capital assets in England. The study demonstrates the particular challenges of a marine natural capital valuation study applied in a clearly defined environmental management context. The valuation study will be used to reflect on the challenges and opportunities of environmental valuation, and in particular stated preference valuation, to marine natural capital to support marine management. 
Subtidal sedimentary seabeds, particularly in offshore areas, are one example of marine habitats that are spatially extensive globally, but have been largely overlooked in the valuation literature. These habitats are generally unseen by the public who are likely unaware of their existence, extent or the ecosystem services they provide. They are characterised by sand, mud and gravel seafloors, which support burrowing and surface-dwelling species. The biodiversity of these habitats is extremely high, and the organisms associated with them perform essential functional roles (Thrush and Dayton 2002). The combination of functioning systems and habitat enables provision of ecosystem services including carbon sequestration, waste remediation and nursery areas to support commercial fish stocks (Galparsoro et al. 2014, Hooper et al. 2017, Salomidi et al. 2012). Furthermore, subtidal sedimentary habitats occupy large spatial areas. For example, sand habitats in deeper water (categorised as habitat type A5.27 deep circalittoral sand by the European Nature Information System) is predicted as the single most prevalent seabed type in the UK, accounting for $20 \%$ of the marine area (McBreen et al. 2011).

These habitats are also under threat, with $68 \%$ of the Southern North Sea, for example, subject to high disturbance as a result of fishing (OSPAR 2017). Such disturbance can affect the wider functioning of the marine system (and the other ecosystem services it provides), the implications of which will depend on the exact habitat type and the fishing gear used. Other marine industries, such as aggregate extraction and the installation of offshore wind farms and subsea cables also impact on sedimentary seabed habitats.

The exploitation of the marine environment therefore needs to be balanced with maintaining ecosystem health, and better understanding of the economic value of subtidal sedimentary habitats would support marine resource management decisions. This study presents a discrete choice experiment survey valuing a set of ecosystem services linked to seabed marine natural capital in the UK section of the North Sea. The study further links directly to management targets for habitats in European Seas through the use of Good Environmental Status as the measure of ecosystem health. Achieving Good Environmental Status is the measure through which the Marine Strategy Framework Directive (European Commission 2008) seeks to achieve the aim of improving marine biodiversity, and is determined based on a series of qualitative descriptors supported by quantitative targets.

In order to address gaps in the valuation literature, the study focuses in particular on (1) Good Environmental Status of offshore seabed habitats; (2) the contribution that exploitation of these habitats makes to the maritime cultural heritage in England; and (3) changes to the health of seabird populations. For seabed habitats and seabirds, the elicited values mainly represent non-use values for changes in the condition of natural capital assets. For maritime cultural heritage the valuation focuses on the changes to the provision of this cultural ecosystem service. 
It is important that new valuation data achieves the stated purpose of supporting decision-making; at present few academic studies are actually taken up in the policy context (Hanley et al. 2015, Laurans et al. 2013). Therefore, the present study was designed in conjunction with the UK's Department for the Environment Food and Rural Affairs (Defra), with the aim of filling an evidence gap they had defined as a priority for UK policy. As stated above, valuation has particular potential for marine planning, and this provided the overarching context for this research. In the UK, marine planning is devolved to the administrations for England, Wales, Northern Ireland and Scotland. In England it is the responsibility of the Marine Management Organisation (MMO), which has designated six regional marine plan areas; this study focuses on the East Marine Plan (EMP) area, where the first Marine Plan in England was implemented.

The EMP area covers a substantial part of the Southern North Sea and thereby supports extensive maritime activity across many different sectors. The economic importance of marketable ecosystem services is well known, with, for example, the EMP area accounting for $67 \%$ of the total area licensed for aggregate extraction in English waters, containing 37\% of offshore wind capacity and hosting England's largest port for shellfish landings (HM Government 2014). The EMP area has eleven specific objectives, which include promoting the sustainable development of economically productive activities and supporting the creation of employment, but also having a healthy, resilient and adaptable marine ecosystem and protecting, conserving and where appropriate recovering, biodiversity (HM Government 2014). Better understanding of the value of the assets, goods and services provided by the extensive subtidal sedimentary habitats within the EMP area will be of significant benefit to managing the trade-offs between economic development and environmental health. Therefore the present study was designed in part to assess the value of a number of ecosystem services and components of marine natural capital in the EMP area which have previously not been quantified. A stated preference approach is used in order to capture the potentially high proportion of non-use value of the goods and services under study.

The remainder of the paper is structured as follows. Section 2 reviews previous valuations of marine natural capital goods and services, and Section 3 outlines the methodology of the discrete choice experiment study as well as the econometric approach to analyse the resulting choice data. Section 4 presents the results, which are discussed in Section 5, and the conclusions drawn are provided in Section 6.

\section{Previous applications of stated preference methods in the marine and coastal environment}

The goods and services that arise from marine natural capital assets can be valued using a range of valuation methods, such as the production function approach (Barbier 2007, 2012, Foley et al. 2010) 
for nursery habitat provision or the travel cost method (e.g. Carr and Mendelsohn 2003, Chae et al. 2012, Rolfe and Gregg 2012) for recreation. However, due to the remoteness and inaccessibility of subtidal sedimentary habitats, particularly those offshore, the principal values held by the general public do not relate to any direct use of these habitats by humans. Only a very small number of people engaging in activities such as scuba diving would come into direct contact with such habitats (although even divers tend to prefer other sites such as rock and reefs), while recreational anglers would derive indirect use value from the role of the habitats in supporting key fish species. Both activities become rarer the further from the shore the habitat is located. Therefore, for most of the general public, subtidal sedimentary seabeds are too remote to generate any direct use value.

However, marine natural capital can be of value to humans directly, in the form of non-use values of the capital asset. Such values comprise existence, bequest and altruistic values (Lazo et al. 1997), i.e. the idea that people value a resource for its mere existence (existence value), the fact that it can be bequeathed to and possibly be used and valued by future generations (bequest value) or can be valued by other people (altruistic value). In the case of subtidal sedimentary seabeds, this channel of valuation is potentially substantial. Non-use values can only be elicited through stated preference methods.

Compared to the valuation of terrestrial environmental public goods as components of natural capital, the valuation of marine natural capital has a shorter history. From early to current applications in the marine realm, stated preference studies have mainly focused on coastal resources, such as beach characteristics (e.g. Barry et al. 2011, Silberman et al. 1992, Silberman and Klock 1988), water quality (Hanley et al. 2003a, Hynes et al. 2013), the impact of coastal marine protected areas (Paltriguera et al. 2018, Peters and Hawkins 2009) and other touristic (use) characteristics of coastal waters (Börger and Piwowarczyk 2016, Rodrigues et al. 2015, Rolfe and Windle 2012, Wielgus et al. 2003, Xuan et al. 2017). Valuation studies of visual impact of offshore (albeit coastal) wind turbines (e.g. Börger et al. 2015, Krueger et al. 2011, Ladenburg and Dubgaard 2007, Westerberg et al. 2013), assess both the value of reduced visibility of turbines from land and ecological impact of the construction of turbine foundations in coastal waters. Another strand in the stated preference literature, starting with the influential Exxon Valdez oil spill study (Carson et al. 1992), has applied stated preference methods to assess damage from specific marine pollution events (e.g. Bishop et al. 2017, Loureiro et al. 2009) and for oil spill prevention more generally in monetary terms (Bishop et al. 2017, Leon et al. 2014, Navrud et al. 2016). More recently there have been efforts to assess the monetary costs of marine plastic pollution on shorelines and in the water column (Abate et al. 2020, Brouwer et al. 2017). 
Stated preference valuations were not applied to offshore and deep-sea environmental goods until the current decade (Aanesen et al. 2015, Börger et al. 2014b, Brouwer et al. 2016, Burton et al. 2015, Jobstvogt et al. 2014, McVittie and Moran 2010, Norton and Hynes 2014, Stefanski and Shimshack 2016, Wattage et al. 2011). Oftentimes such valuation studies were driven by specific marine and coastal policies, and the aim was to ascertain the welfare effects of implementing the respective policy. For instance, McVittie and Moran (2010) values marine ecosystem service conservation to support development of the Marine Bill that resulted in the UK Marine and Coastal Access Act. The study by Börger et al. (2014b) was conducted against the background of plans to designate the UK section of the Dogger Bank in the North Sea as an offshore marine protected area under the EU Habitats Directive (European Commission 1992). A number of studies assess the welfare implications of achieving Good Environmental Status under the EU Marine Strategy Framework Directive for instance in Latvian (Pakalniete et al. 2017), Estonian (Tuhkanen et al. 2016), Finnish (Nieminen et al. 2019) and Irish waters (Norton and Hynes 2014). The present study continues this approach of advancing the use of stated preference environmental valuation to components of marine natural capital, which have thus far not been valued in monetary terms. The focus is on the achievement of Good Environmental Status of subtidal seabeds in the North Sea and the changes in ecosystem service provision that go along with it.

\section{Methodology}

\subsection{Development of the survey instrument}

A discrete choice experiment was used to value changes to components of marine natural capital in the East Marine Plan (EMP) area in the southern part of the English North Sea (Figure 1). A general review of marine valuation studies in the UK was used to identify components of natural capital that had thus far been neglected by valuation efforts (Hooper et al. 2019a, b). The selection of components of marine natural capital to be valued was further refined in an international expert and stakeholder workshop conducted prior to this study (Hooper et al. 2019b). Consequently, the focus of the study was valuation of the Good Environmental Status of subtidal sediment and the provision of related goods and services. The subsequent steps of the development of the set of choice attributes and their description as well as of the wider survey questionnaire was done by an interdisciplinary research team and based on recent recommendations for stated preference methods (Börger et al. 2018, Johnston et al. 2017). To inform attribute selection and description, and obtain feedback on the draft choice attributes and survey questionnaire, focus groups were held in four cities across England between 9 and 25 October 2018. The locations (Plymouth, Birmingham, Hull and Ipswich) were selected to ensure representation from those living near the coast and inland across the whole 
sampling area, with varying proximity to the case study site, and from different regions of England. Nine participants (recruited by market research companies) attended each focus group, and were selected to ensure a balance in terms of age, income and gender. A detailed account of the focus groups and the resulting changes made to the description of the choice attributes can be found in Appendix 4 in Börger et al. (2019). These changes were made to the survey questionnaire before online piloting.

Figure 1: Location of the East Marine Plan (EMP) area (in light blue) and adjacent counties of England

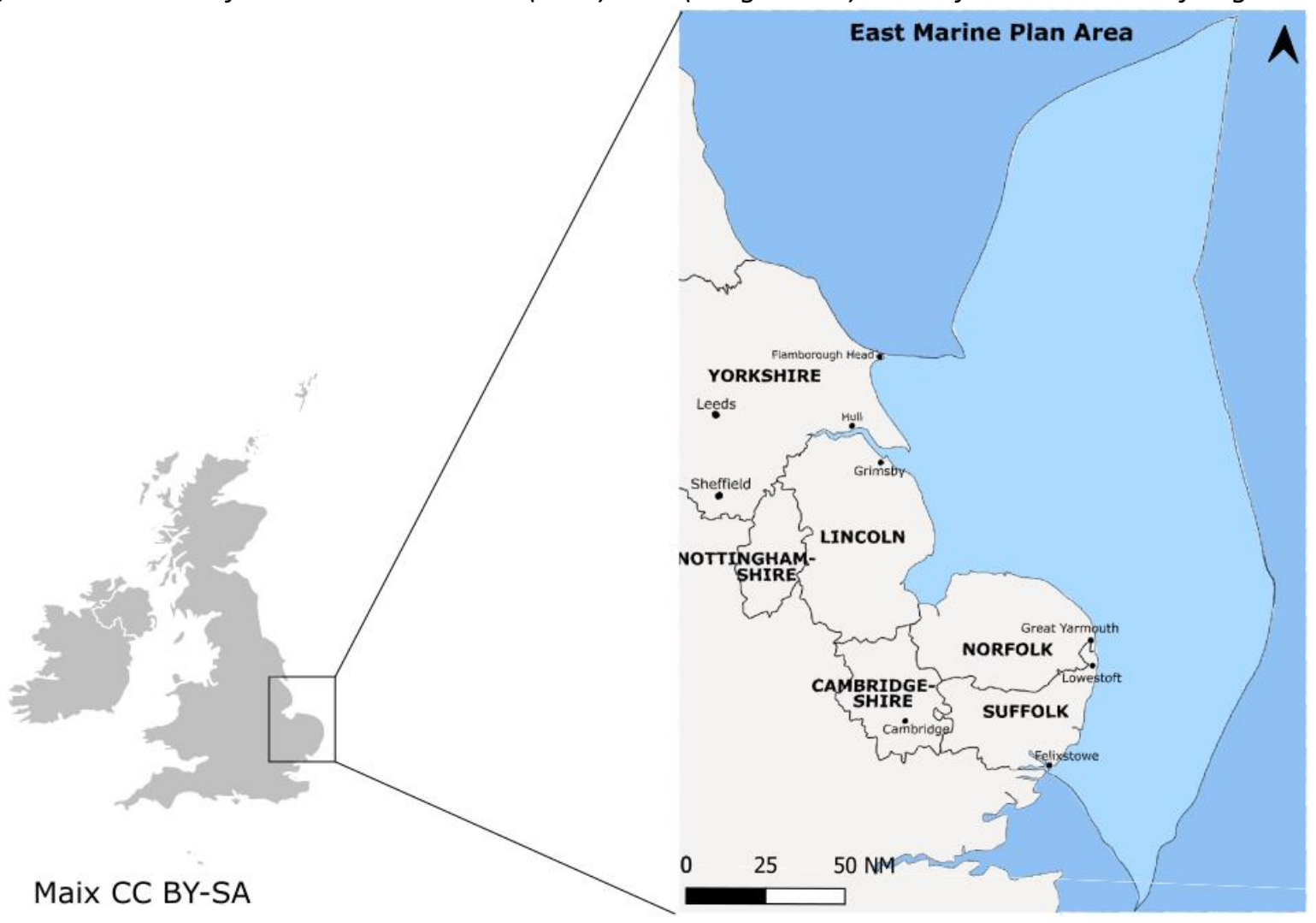

The choice attributes (Table 1) were presented to respondents as the outcomes of different management options to restore the seabed, which could include activity, place and time restrictions. The first choice attribute describes the share of the EMP area where the seabed is in Good Environmental Status. Good Environmental Status was chosen as a recognised management target under the Marine Strategy Framework Directive, and thus maintained the direct policy focus. The development of this attribute was informed by the European Commission's descriptors of Good Environmental Status

- Descriptor 6, Sea-floor Integrity: "Sea-floor integrity is at a level that ensures that the structure and functions of the ecosystems are safeguarded and benthic ecosystems, in particular, are not adversely affected" (European Commission 2016a). 
- Descriptor 1, Biodiversity: "The quality and occurrence of habitats and the distribution and abundance of species are in line with prevailing physiographic, geographic and climatic conditions." (European Commission 2016b).

The levels of this attribute are based on the OSPAR Intermediate Assessment which currently classifies $68 \%$ of the South North Sea (which matches closely to the EMP area) as highly disturbed by fishingrelated abrasion (OSPAR 2017). Consequently, a baseline level of 35\% of the EMP area being in good status is used. Improvements to $50 \%$ and $70 \%$ of the EMP area in Good Environmental Status are offered as alternatives.

The second attribute captures the effect of marine planning on maritime cultural heritage in terms of potential impacts to traditional livelihoods in coastal communities. When it comes to cultural ecosystem services the valuation literature has so far mainly focused on recreation (Westerberg et al. 2013) and visual amenity in the context of offshore energy installations (e.g. Ladenburg and Dubgaard 2007). Valuations of cultural 'heritage', first suggested by Claesson (2011), have been limited to the context of historic buildings (e.g. Báez and Herrero 2012, eftec 2014) and submerged shipwrecks (Whitehead and Finney 2003).

Durán et al. (2015) uses a stated preference survey to value maritime heritage in terms of jobs, architechture, knowledge and folklore in traditional fishing communities in Spain. With the exception of this study, the economic value of maritime heritage in terms of the importance of the activities that have shaped, and continue to shape, the identities of coastal communities appears not to have been studied. Changes in maritime activities are also an appropriate trade-off in the context of the current study, as restrictions in bottom trawling to protect seabed habitats, for example, could result in a shift from activities that are perceived as 'traditional' (even though the actual practices may not be) to newer industries such as energy or the recreation and tourism sector. The stated preference approach allows this cultural value to be determined and so provides a wider perspective than simply the market-based economic impacts of changing employment patterns, which are measured by other means.

In a continuing long-term trend, the number of fishermen on vessels registered in the UK declined by 9\% between 2007 and 2017 (Marine Management Organisation 2018). Consequently, the attribute's business-as-usual level is a loss of jobs in traditional maritime industries of $10 \%$ over ten years. Alternative levels describe more rapid losses of $25 \%$ or $50 \%$ of jobs in these industries over a ten-year period. 
Table 1: Choice attributes and levels

\begin{tabular}{|c|c|c|}
\hline Attribute & Description & Levels \\
\hline $\begin{array}{l}\text { Condition of } \\
\text { the seabed }\end{array}$ & $\begin{array}{l}\text { - Seabed habitats function more naturally when disturbance by human } \\
\text { activities is reduced. } \\
\text { - More natural seabeds support healthy seas because many species } \\
\text { (including ones we eat or enjoy watching) rely directly or indirectly on } \\
\text { the seabed to feed, hide, rest or reproduce. } \\
\text { - This more natural condition of the seabed is measured according to } \\
\text { recognised standards called Good Environmental Status }\end{array}$ & $\begin{array}{l}35 \% / 50 \% / 70 \% \\
\text { of the seabed in } \\
\text { the East Marine } \\
\text { Plan area has } \\
\text { been restored to } \\
\text { a natural } \\
\text { condition }\end{array}$ \\
\hline $\begin{array}{l}\text { Way of life } \\
\text { in coastal } \\
\text { communities }\end{array}$ & $\begin{array}{l}\text { - Some seafaring activities have been carried out for many years, and } \\
\text { are part of the heritage and way of life in certain coastal } \\
\text { communities. } \\
\text { - Management to improve the condition of the seabed may result in } \\
\text { some jobs in these traditional industries being lost, although they } \\
\text { may be replaced by jobs in other or newer marine industries such as } \\
\text { tourism, fish farming or servicing offshore wind farms. }\end{array}$ & $\begin{array}{l}10 \% / 25 \% / 50 \% \\
\text { of jobs in } \\
\text { traditional } \\
\text { industries are lost } \\
\text { in } 10 \text { years }\end{array}$ \\
\hline $\begin{array}{l}\text { Seabird } \\
\text { population }\end{array}$ & $\begin{array}{l}\text { - Protecting seabeds in the East Marine Plan area will increase the food } \\
\text { supply for certain seabirds and so maintain or increase their numbers. } \\
\text { - However, management for seabed protection could see an increase in } \\
\text { activities that don't damage the seabed but have direct impacts on } \\
\text { seabirds, for example through accidental capture on hooks or in mid- } \\
\text { water nets. } \\
\text { - This could cause the number of seabirds to decline. } \\
\text { - For the recognised standard of Good Environmental Status, at least } \\
\text { 75\% of species in the area should have a healthy population size }\end{array}$ & $\begin{array}{l}66 \% \text { / } 40 \% / 75 \% \\
\text { of species in the } \\
\text { East Marine Plan } \\
\text { area have a } \\
\text { healthy } \\
\text { population size }\end{array}$ \\
\hline Annual tax & $\begin{array}{l}\text { - There will be costs involved in changing the management measures in } \\
\text { the marine plan area, for example in developing schemes to } \\
\text { encourage those using the sea to adapt the way they work in order to } \\
\text { protect the health of the seabed and marine life. } \\
\text { - The government therefore needs to raise additional funds through } \\
\text { taxes. } \\
\text { Once the changes in the way marine activities operate have become } \\
\text { established, the need for additional funds will decrease. } \\
\text { The tax is payable by all households in England every year for the next } \\
5 \text { years. If the overall funds people are willing to contribute do not } \\
\text { cover the cost of implementing the plan, it cannot be put into action. }\end{array}$ & $\begin{array}{l}£ 0 ; £ 10 ; £ 20 ; £ 50 ; \\
£ 75 ; £ 100 ; £ 150\end{array}$ \\
\hline
\end{tabular}

Notes: Business-as-usual levels in italics

The third attribute depicts a trade-off between changes of seabed conditions and more mobile marine wildlife. The logic is that substantially reducing activities which cause abrasion of the seabed, such as bottom-trawl fishing, would have to be offset by increased use of mid-water or static fishing gear, or more rapid development of alternative maritime sectors, such as offshore energy generation. This would affect prey availability, risk of entanglement, collision, light or noise disturbance and thus potentially the health of the populations of a range of marine mammal and seabird species. Since more valuations already exist in the literature for marine mammals (Hooper et al. 2019b), the 
proportion of seabird species with healthy population sizes was selected for this attribute, again to relate to a defined Good Environmental Status target. According to the OSPAR Intermediate Assessment (OSPAR 2017), the current and target level for species in the Greater North Sea region with healthy population sizes is $67 \%$ and $75 \%$, respectively. This is reflected in the attribute levels, which have $66 \%$ as the business-as-usual case with an increase to $75 \%$ and a potential decline to $40 \%$ as alternatives. Care was taken to develop the attributes which can be independently variable so that the levels can be independently valued. Seabird populations, for instance, might profit from fishing restrictions due to increased food availability. Consequently, there is no correlation in the provision of these attributes as improvements in the seabed condition can go along with both improvements and deteriorations in the health of seabird populations and different rates of decline of jobs in traditional maritime industries, depending on the specific mix of management measures.

To be able to derive estimates of marginal WTP for changes in the above attributes, the DCE included an annual tax as monetary attribute. Such a generic tax had been used successfully in comparable valuation studies in the UK policy context (e.g. McVittie and Moran 2010). Focus group participants indicated that this specification was preferred to other options such as council tax. The tax was limited to five years.

These attributes and their levels were used to generate a Bayesian experimental design, for a pilot survey, with zero priors consisting of 18 choice sets using the software Ngene (ChoiceMetrics 2012). These were separated into two blocks, so that each respondent completed a series of nine choice sets. Choice order was rotated, so that different respondents started the series from different choice sets. The online pilot survey with was conducted between 15 and 17 November 2018 with $N=92$ respondents to test the design. Coefficient estimates from a random parameters logit model (see Section 3.2) based on the pilot data were used to generate a D-efficient design for the main survey with the same specifications (i.e. nine choice sets per respondents in two blocks). An example choice card is displayed in Figure 2.

In addition to the choice experiment component, the final survey questionnaire included the following sections. ${ }^{1}$ Part I asked whether respondents had visited the EMP area and the types of activities they engaged in within the area and on UK coasts more generally. Maps of both the EMP area and the adjacent counties were included. Subsequently, a quiz with five multiple-choice knowledge questions was included to test respondents' prior level of understanding about the marine environment. The use of knowledge quizzes to assess prior knowledge of the survey topic and use this to explain differences in preference has recently become increasingly popular in stated preference research (LaRiviere et al. 2014, Needham and Hanley 2019). The second part of the questionnaire

\footnotetext{
${ }^{1}$ The full questionnaire can be found in the appendix of Börger et al. (2019).
} 
introduced the concept of marine planning, and provided a map and introduction to the EMP area. The explanations further specified the management options for the EMP area, including place-, activity-, and time-based restrictions such as closed seasons and marine protected areas. Respondents were informed about national goals to restore seabed habitats, and the main characteristics of these habitats were set out.

Figure 2: Example of a choice card displaying one choice set

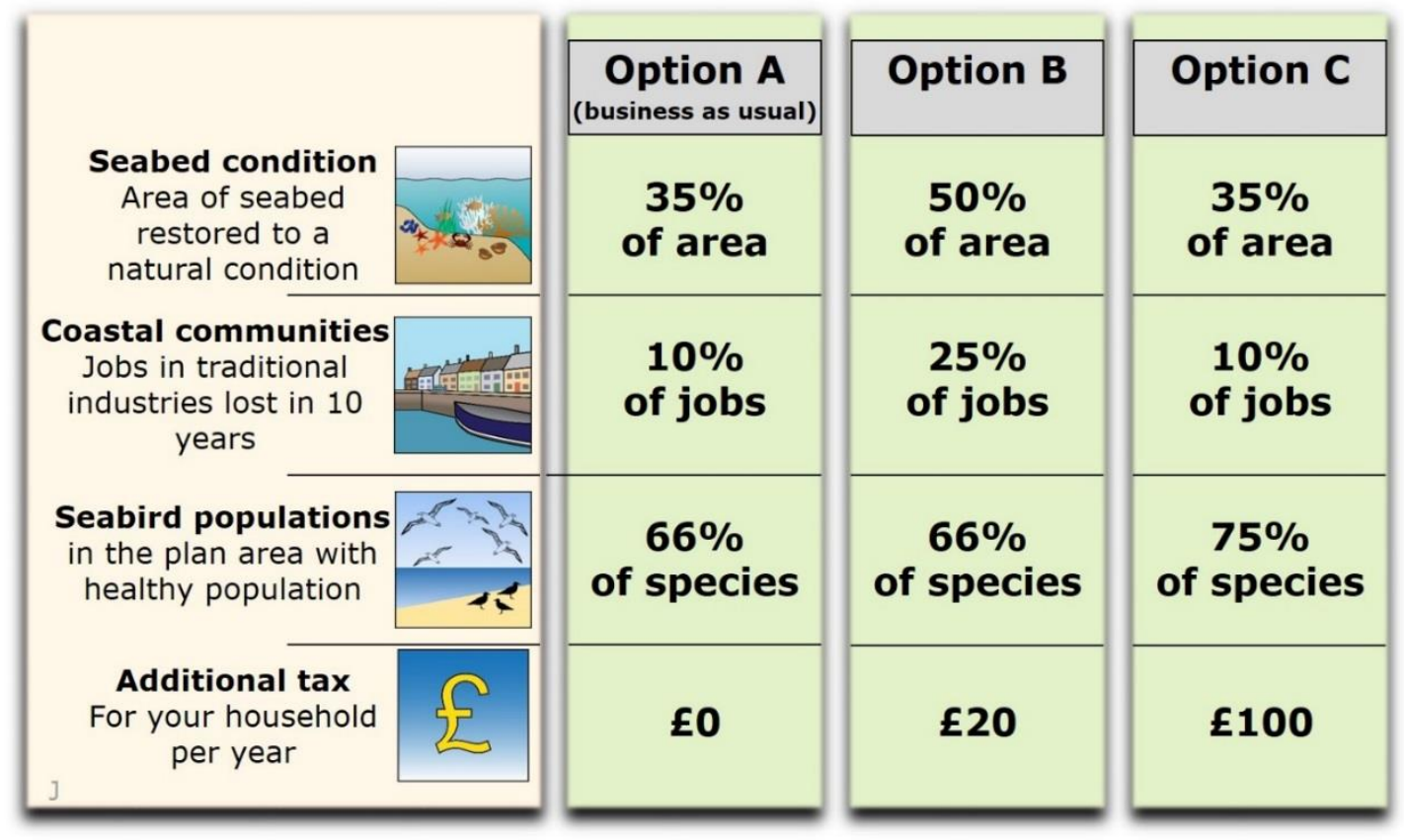

This part was followed by the choice experiment component. After the introduction of the four choice attributes, respondents received instructions of how to complete the subsequent choice tasks. An exemplary choice card accompanied by some explanatory test was displayed to further clarify this process. The last part of the questionnaire featured a set of attitudinal and socio-demographic questions.

\subsection{Analysis of choice data}

The choice modelling techniques used to analyse the resulting discrete choice data are based on the random utility model (RUM) (McFadden 1974). According to the RUM the utility of respondent $n$ obtained from choosing option $i$ in choice situation $t$ can be expressed as

$$
U_{n i t}=X_{n i t} \beta_{n}+\varepsilon_{n i t} .
$$

$X_{n i s}$ is a vector of the choice attributes in that option. $\varepsilon_{n i t}$ is an option-specific error term which follows a type I extreme value distribution with variance $\pi^{2} / 6 s^{2}$, where the scale parameter $s$ is 
typically set to 1 for identification. Setting $\beta_{n}=\beta$ is the multinomial logit (MNL) model which assumes that there is no heterogeneity in preferences across respondents. Setting instead $\beta_{n}=\beta+\eta_{n}$ assumes that preference coefficients are respondent-specific and follow a random distribution with mean $\beta$ and variance $\operatorname{var}\left(\eta_{n}\right)$. This is the mixed logit model (Revelt and Train 1998). Since marginal WTP for choice attribute (level) $a$ is computed as $W T P_{a}=-\beta_{a} \gamma^{-1}$ the use of the random parameters model implies the need to calculate this as the ratio of two random parameter distributions. Depending on the particular distributional assumptions this procedure can lead to implausibly high or low estimates or undefined moments of the resulting WTP distribution. To overcome this issue, Train and Weeks (2005) proposed an equivalent specification which estimates preferences in WTP-space and allows specification of the distributional form of marginal WTP directly. To this end, (1) can be rewritten as

$$
U_{n i t}=X_{n i t}^{-c} \beta_{n}^{-c}+c_{n i t} \gamma_{n}+\varepsilon_{n i t}
$$

where $X_{n i t}^{-c}$ is a vector of non-monetary attributes of option $i$ in situation $t$ for respondent $n$, and $c_{\text {nit }}$ is the cost attribute of that option. Dividing the first two summands in (2) by the marginal utility of the cost attribute, $\gamma_{n}$, and replacing $\beta_{n}^{-c} / \gamma_{n}=\delta_{n}$ yields

$$
U_{n i s}=\gamma_{n}\left(X_{n i t}^{-c} \delta_{n}+c_{n i t}\right)+\varepsilon_{n i t} .
$$

$\delta_{n}$ is a vector of coefficients to be estimated, the elements of which directly capture marginal WTP for the respective (non-monetary) attribute. These are assumed to be normally distributed, and the cost coefficient to be log-normally distributed.

Assuming that in every choice set $t=1, \ldots, T_{n}$ respondent $n$ chooses the option that maximises their utility, the probability of a series of choices $y_{n}=\left\{i_{n 1}, \ldots, i_{n T_{n}}\right\}$ by respondent $n$ is

$$
\operatorname{Pr}\left(y_{n}\right)=\prod_{t=1}^{T_{n}} \frac{\exp \left(\gamma_{n}\left(X_{n i} \delta_{n}+c_{n i}\right)\right)}{\sum_{j=1}^{J} \exp \left(\gamma_{n}\left(X_{n j} \delta_{n}+c_{n j}\right)\right)}
$$

Summing these probabilities over all respondents $n$ and taking the natural logarithm gives the loglikelihood function. Due to the random parameters in the model, an analytical solution to the loglikelihood does not exist, so simulated maximum likelihood is used. These models are implemented employing the user-written routines in Matlab from Czajkowski et al. (2017) and Pakalniete et al. (2017). ${ }^{2}$ The model uses 5,000 Sobol draws to simulate the likelihood. Multiple sets of starting values were used to ensure attainment of a global likelihood maximum.

\footnotetext{
${ }^{2}$ The codes for these routines are available under the Creative Commons BY 4.0 license at github.com/czaj/DCE.
} 


\section{Results}

\subsection{Sample characteristics and knowledge of and engagement with the marine environment}

The online survey was conducted in December 2018 by the market research company Marketing Means. Respondents were recruited from a pre-existing survey panel owned by Snap Surveys using quota sampling with the characteristics gender, age group and region. In total, 1,212 completed questionnaires were received. Comparing sample characteristics on the three sampling criteria shows that, despite having slightly fewer male respondents, the sample is representative of the English population at large (Table 2).

Table 2: Sample characteristics

\begin{tabular}{lrr}
\hline \multicolumn{1}{c}{ Variable } & Sample & Population $^{\text {a }}$ \\
\hline \hline Male & $46.7 \%$ & $49.4 \%$ \\
Age group & & \\
18 to 24 & $7.9 \%$ & $10.9 \%$ \\
25 to 34 & $16.3 \%$ & $17.4 \%$ \\
35 to 44 & $17.6 \%$ & $16.2 \%$ \\
45 to 54 & $20.0 \%$ & $17.8 \%$ \\
55 to 64 & $16.3 \%$ & $14.8 \%$ \\
65 to 74 & $14.6 \%$ & $12.6 \%$ \\
75 and older & $7.3 \%$ & $10.4 \%$ \\
Region & & \\
East Midlands & $9.4 \%$ & $8.6 \%$ \\
East of England & $11.2 \%$ & $11.1 \%$ \\
London & $15.2 \%$ & $15.9 \%$ \\
North East & $5.1 \%$ & $4.8 \%$ \\
North West & $13.8 \%$ & $13.1 \%$ \\
South East (excl. London) & $17.6 \%$ & $16.3 \%$ \\
South West & $10.9 \%$ & $10.0 \%$ \\
West Midlands & $6.4 \%$ & $10.5 \%$ \\
Yorkshire \& Humberside & $10.5 \%$ & $9.8 \%$ \\
\hline Notes: N=1,212. ${ }^{a}$ Office for National & Statistics mid-2017 & population \\
estimates & &
\end{tabular}

Respondents further completed a knowledge quiz consisting of five questions (Table 3). A quiz score can be computed by summing a respondent's correct responses. This score ranges from 0 to 5 and serves as an indicator of a respondent's prior general knowledge of the marine environment. The quiz score will further be used in interactions with the alternative-specific constant to assess the validity of the choice responses (Section 4.3). 
Table 3: Knowledge quiz about the marine environment

\begin{tabular}{|c|c|c|}
\hline Quiz question & Answer options $^{\mathrm{a}}$ & $\%$ correct \\
\hline What do you think is the most common seabed type for English waters? & $\begin{array}{c}\text { Mud; Fine sand; } \\
\text { Coarse sand, gravel, } \\
\text { pebbles; Don't know }\end{array}$ & $63 \%$ \\
\hline $\begin{array}{l}\text { Which of the following types of fish DOES NOT live mostly on or near the } \\
\text { seabed? }\end{array}$ & $\begin{array}{l}\text { Herring; Cod; Plaice; } \\
\text { Don't know }\end{array}$ & $37 \%$ \\
\hline What is the average depth of the North Sea? & $\begin{array}{c}20 \text { metres; } 90 \\
\frac{90}{\text { metres; }} 120 \text { metres; } \\
\text { Don't know }\end{array}$ & $35 \%$ \\
\hline Which of the following seabirds IS NOT found around the English coast? & $\begin{array}{l}\text { Gannett; Puffin; } \\
\frac{\text { Albatross; Don't }}{\text { know }}\end{array}$ & $65 \%$ \\
\hline Which of the following lives buried in the seabed? & $\begin{array}{l}\text { Limpet; Mussel; } \\
\text { Clam; Don't know }\end{array}$ & $50 \%$ \\
\hline
\end{tabular}

Notes: $\mathrm{N}=1,212$ respondents. ${ }^{\text {a }}$ Correct answer in underlined.

Respondents were also asked about their engagement with the marine environment, across the UK as a whole and along the EMP area coast in particular. Respondents could indicate whether they had done activities "...anywhere in the UK" or "...on the East Coast" or both (Table 4). Results show that relaxing on the beach and paddling (69\% of respondents have done that at least once), walking, cycling or running on beaches or coastal paths (61\%) and playing with children on the beach (56\%) were most popular at all UK coasts. For the stretch on the East Coast between Flamborough Head and Felixstowe (the EMP area) the two most frequently stated activities were the same (i.e. relaxing on the beach or paddling and walking, cycling or running on beaches and coastal paths). The third most popular was appreciating the coastal scenery from your car (e.g. at a viewpoint) (50\%). Approximately half of respondents had undertaken activities in the EMP area compared to those who had done the respective activity anywhere in the UK.

By summing responses to these questions over all activities two further scores were computed. A score for "anywhere in the UK" ranges from 0 to 13 and indicates the number of activities a respondent has engaged in at any of the UK coasts. The score for the East Coast indicates this for the coast adjacent to the EMP area. These scores will also be interacted with the attribute-specific constant to assess response validity in Section 4.3 . 
Table 4: Uses of the coastal and marine environment in the study area and the UK as a whole

\begin{tabular}{lcc}
\hline Have you ever done any of the following in coastal areas... & $\begin{array}{c}\text { Share "Yes" responses } \\
\text { anywere in } \\
\text { the UK }\end{array}$ & $\begin{array}{c}\text {...on the East } \\
\text { Coast }\end{array}$ \\
\hline \hline a. Appreciating coastal scenery from your car (e.g. at a viewpoint) & $50 \%$ & $24 \%$ \\
b. Walking with a dog on beaches or coastal paths & $35 \%$ & $14 \%$ \\
c. Walking (without a dog)/cycling/ running on beaches or coastal paths & $61 \%$ & $31 \%$ \\
d. Relaxing on the beach or paddling & $69 \%$ & $30 \%$ \\
e. Playing with children on the beach & $56 \%$ & $23 \%$ \\
f. Swimming & $48 \%$ & $15 \%$ \\
g. Snorkelling/scuba diving & $11 \%$ & $6 \%$ \\
h. Non-powered watersports (e.g. surfing, windsurfing, kayaking, sailing) & $15 \%$ & $7 \%$ \\
i. Powered watersports (e.g. waterskiing, jetskiing, powerboating) & $11 \%$ & $7 \%$ \\
j. Angling/crabbing & $22 \%$ & $11 \%$ \\
k. Bird watching & $28 \%$ & $16 \%$ \\
l. Other wildlife watching & $29 \%$ & $15 \%$ \\
m. Wildfowling (hunting duck \& geese) & $8 \%$ & $6 \%$ \\
\hline Respondents who did at least one of the above activities
\end{tabular}

Notes: $\mathrm{N}=1,212$ respondents

\subsection{Valuing components of marine natural capital}

This section presents an analysis of the choice data. A multinomial logit (MNL) model in WTP-space (Train and Weeks 2005) is displayed in Table 5. Since the model is estimated in WTP-space, attribute coefficients can be directly interpreted as estimates of mean marginal WTP. On average, respondents show positive WTP of $£ 53.57$ for an increase of the seabed area in Good Environmental Status from a baseline of $35 \%$ of the EMP area to $50 \%$ (SEABED50) and an even higher marginal WTP (f72.37) for the increase to $70 \%$ of the EMP area (Table 6). Respondents expect welfare losses from more rapid losses of maritime cultural heritage, as indicated by the negative coefficients of JOBS25 and JOBS50. There is a negative WTP of $f-16.88$ ( $f-38.23$ ) for losing $25 \%(50 \%)$ of jobs in traditional maritime industries over ten years compared to a baseline of a $10 \%$ loss. When it comes to changes to the share of seabird species with healthy population sizes, respondents value an increase from a baseline of $66 \%$ to $75 \%$ at $£ 24.52$ (BIRDS75) and a decrease to $40 \%$ at $f-38.02$. The cost coefficient in this model is significant and positive, which is a result of the sign reversal of the COST attribute. 
Table 5: MNL and MXL models in WTP-space

\begin{tabular}{|c|c|c|c|c|c|c|}
\hline & \multirow{2}{*}{\multicolumn{2}{|c|}{$\begin{array}{c}\text { MNL } \\
\text { Means }\end{array}$}} & \multicolumn{4}{|c|}{ MXL } \\
\hline & & & \multicolumn{2}{|l|}{ Means } & \multicolumn{2}{|c|}{ Standard deviation } \\
\hline & coef. & s.e. & coef. & s.e. & coef. & s.e. \\
\hline ASC_CHANGE & -4.963 & (5.544) & $46.575^{* * *}$ & (3.927) & $69.367 * * *$ & $(6.712)$ \\
\hline SEABED50 & $53.569 * * *$ & (4.749) & $49.101 * * *$ & (3.650) & $53.451 * * *$ & $(4.840)$ \\
\hline SEABED70 & $72.374 * * *$ & (4.945) & $68.702 * * *$ & (4.371) & $69.587 * * *$ & (4.327) \\
\hline JOBS25 & $-16.876 * * *$ & (3.119) & $-21.580 * * *$ & (2.794) & $33.605^{* * *}$ & (1.753) \\
\hline JOBS50 & $-38.228 * * *$ & (3.309) & $-52.860 * * *$ & $(4.232)$ & $69.611 * * *$ & $(2.866)$ \\
\hline BIRDS40 & $-38.021 * * *$ & (3.525) & $-36.846 * * *$ & (3.674) & $33.763 * * *$ & (2.416) \\
\hline BIRDS75 & $24.518 * * *$ & (3.634) & $25.306 * * *$ & (2.819) & $35.016 * * *$ & (3.771) \\
\hline -COST & $0.012 * * *$ & $(0.000)$ & $0.123 * * *$ & $(0.024)$ & 0.507 & $(0.313)$ \\
\hline LL at convergence & $-10,775$ & & $-8,405$ & & & \\
\hline LL at constant(s) only & $-11,825$ & & $-11,825$ & & & \\
\hline McFadden's pseudo- $R^{2}$ & 0.089 & & 0.289 & & & \\
\hline $\mathrm{BIC} / \mathrm{n}$ & 1.982 & & 1.579 & & & \\
\hline Sobol draws & - & & 5,000 & & & \\
\hline
\end{tabular}

Notes: $\mathrm{N}=1,212$ respondents; 10,908 choices. s.e. - standard error. ${ }^{* * *}$ indicate significance at the $1 \%$-level of confidence. In the MXL model, all coefficients are assumed to be normally distributed and correlated except for the cost coefficient which is assumed to be log-normally distributed.

The estimates of the MXL model in WTP-space on the right-hand side of Table 5 confirm the above findings, yet estimates of marginal WTP differ slightly. This model also highlights the existence of significant heterogeneity in preferences and marginal WTP as indicated by the significant standard deviation coefficients for all non-monetary attributes. Due to the markedly better fit to the data of this model compared to the MNL, the main estimates of marginal WTP from this study are taken from the MXL model. Marginal WTP estimates and confidence intervals from the MXL model are also included in Table 6.

Besides assuming normally distributed, i.e. heterogeneous, marginal WTP estimates across the sample, the MXL model in Table 5 further assumed these random coefficients to be correlated. The correlation coefficients between the random preference/WTP coefficients are displayed in Table 7. Norton and Hynes (2014) use a similar analysis of correlation between attributes. ${ }^{3}$ As expected random coefficients for different levels of the same attribute (i.e. the three pairings of SEABED50 and SEABED70, JOBS25 and JOBS50, and BIRDS40 and BIRDS75) are (highly) correlated.

Another striking finding is that preferences for Good Environmental Status of the seabed and health populations of seabirds are strongly correlated. Respondents with a high WTP for improvements in seabed integrity are also willing to pay to ensure health seabird populations.

\footnotetext{
${ }^{3}$ Note, however, that Norton and Hynes (2014) use a preference space model with normally distributed attribute coefficients and a cost coefficient which does not vary across respondents.
} 
Preferences regarding jobs losses in traditional maritime industries, however, appear to be more independent. The normally distributed preference coefficient for JOBS25 is not correlated with any other attribute, and the coefficient for JOBS50 only with SEABED70. This indicates that a high or low (negative) WTP for losses of maritime heritage is not related to valuations of ecological changes in the study area, such as improvements in seabed integrity and the viability of seabird populations.

Table 6: Estimates of marginal WTP from MXL model in WTP-space

\begin{tabular}{|c|c|c|c|}
\hline \multirow[t]{2}{*}{$\begin{array}{l}\text { Variable } \\
\text { name }\end{array}$} & \multirow[t]{2}{*}{ Change in attribute level } & \multicolumn{2}{|c|}{$\begin{array}{l}\text { Marginal WTP per household in England } \\
\text { per year for } 5 \text { years }{ }^{\mathrm{a}}\end{array}$} \\
\hline & & based on MNL & based on MXL \\
\hline SEABED50 & $\begin{array}{l}\text { Increase from } 35 \% \text { to } 50 \% \text { in the proportion of the } \\
\text { seabed in the East Marine Plan area that has been } \\
\text { restored to a natural condition }\end{array}$ & $\begin{array}{c}f 53.67 \\
{[44.26-62.88]}\end{array}$ & $\begin{array}{c}£ 49.10 \\
{[41.89-56.24]}\end{array}$ \\
\hline SEABED70 & $\begin{array}{l}\text { Increase from } 35 \% \text { to } 70 \% \text { in the proportion of the } \\
\text { seabed in the East Marine Plan area that has been } \\
\text { restored to a natural condition }\end{array}$ & $\begin{array}{c}f 72.37 \\
{[62.68-82.07]}\end{array}$ & $\begin{array}{c}£ 68.70 \\
{[59.93-77.48]}\end{array}$ \\
\hline JOBS25 & $\begin{array}{l}\text { Increase from } 10 \% \text { to } 25 \% \text { in the proportion of jobs } \\
\text { in traditional industries that are lost in } 10 \text { years }\end{array}$ & $\begin{array}{c}f-16.88^{b} \\
{[-22.99--10.76]}\end{array}$ & $\begin{array}{c}f-21.58^{b} \\
{[-27.19--16.07]}\end{array}$ \\
\hline JOBS50 & $\begin{array}{l}\text { Increase from } 10 \% \text { to } 50 \% \text { in the proportion of jobs } \\
\text { in traditional industries that are lost in } 10 \text { years }\end{array}$ & $\begin{array}{c}f-38.23^{b} \\
{[-44.71--31.74]}\end{array}$ & $\begin{array}{c}f-52.86^{b} \\
{[-61.42--44.44]}\end{array}$ \\
\hline BIRDS40 & $\begin{array}{l}\text { Decrease from } 66 \% \text { to } 40 \% \text { in the proportion of } \\
\text { seabirds with a healthy population size }\end{array}$ & $\begin{array}{c}f-38.02^{b} \\
{[-44.94--31.11]}\end{array}$ & $\begin{array}{c}f-36.85^{b} \\
{[-44.04--29.73]}\end{array}$ \\
\hline BIRDS75 & $\begin{array}{l}\text { Increase from } 66 \% \text { to } 75 \% \text { in the proportion of } \\
\text { seabirds with a healthy population size }\end{array}$ & $\begin{array}{c}f 24.52 \\
{[17.40-31.64]}\end{array}$ & $\begin{array}{c}f 25.31 \\
{[19.69-31.07]}\end{array}$ \\
\hline
\end{tabular}

Notes: $95 \%$ confidence intervals in square brackets. ${ }^{a}$ derived from the MNL and MXL models in Table $5 .{ }^{\mathrm{b}}$ negative values indicate an expected welfare loss

Table 7: Correlation matrix of random coefficients (based on MXL model in Table 5)

\begin{tabular}{lcccccccc}
\hline & ASC_CHANGE & SEABED50 & SEABED70 & JOBS25 & JOBS50 & BIRDS40 & BIRDS75 & COST \\
\hline \hline ASC_CHANGE & 1 & & & & & & & \\
SEABED50 & $0.814^{* * *}$ & 1 & & & & & & \\
SEABED70 & $0.656^{* * *}$ & $0.944^{* * *}$ & 1 & & & & & \\
JOBS25 & 0.223 & -0.097 & -0.142 & 1 & & & & \\
JOBS50 & $0.205^{* * *}$ & -0.108 & $-0.175^{* * *}$ & $0.994^{* * *}$ & 1 & & & \\
BIRDS40 & $0.172^{* *}$ & $-0.251^{* * *}$ & $-0.381^{* * *}$ & 0.182 & 0.159 & 1 & & \\
BIRDS75 & $0.801^{* * *}$ & $0.926^{* * *}$ & $0.880^{* * *}$ & -0.031 & -0.049 & $-0.327 * * *$ & 1 & \\
COST & -0.560 & -0.833 & -0.740 & 0.250 & 0.220 & 0.243 & -0.621 & 1 \\
\hline
\end{tabular}

*** and $* *$ indicate significance at the $1 \%$ and $5 \%$-level of confidence, respectively.

\subsection{Determinants of choice responses}


To test the validity of the choice responses obtained in the survey, a MXL model with interactions between the alternative-specific constant indicating the change options (ASC_CHANGE) and a number of respondent-specific variables is presented in Table $8 .{ }^{4}$ ASC_CHANGE is 1 for any of the two change options (Option B or C on the choice cards) and 0 for the business-as-usual option (Option A). Among the respondent-specific variables, dummy variables are effects coded and continuous variables are transformed into the z-score.

Table 8: MXL model in WTP-space with interactions

\begin{tabular}{|c|c|c|c|c|}
\hline & \multicolumn{2}{|c|}{ Means } & \multicolumn{2}{|c|}{ Standard Deviations } \\
\hline & coef. & s.e. & coef. & s.e. \\
\hline ASC_CHANGE & $21.026 * * *$ & $(4.008)$ & $74.942 * * *$ & $(4.646)$ \\
\hline SEABED50 & $64.020 * * *$ & $(4.225)$ & $78.239 * * *$ & $(3.504)$ \\
\hline SEABED70 & $85.074 * * *$ & $(4.657)$ & $93.434 * * *$ & (3.540) \\
\hline JOBS25 & $-19.569 * * *$ & $(2.693)$ & $30.792 * * *$ & $(2.030)$ \\
\hline JOBS50 & $-57.577 * * *$ & $(4.069)$ & $73.528 * * *$ & $(2.834)$ \\
\hline BIRDS40 & $-35.994 * * *$ & $(3.510)$ & $33.653 * * *$ & $(2.054)$ \\
\hline BIRDS75 & $32.164 * * *$ & $(2.545)$ & $47.925 * * *$ & $(2.551)$ \\
\hline -COST & $0.149 * * *$ & $(0.031)$ & $0.706 *$ & $(0.389)$ \\
\hline \multicolumn{5}{|l|}{ Interactions with ASC_CHANGE } \\
\hline Live within $10 \mathrm{~m}$ of coast (dummy) & $4.912 * * *$ & $(1.029)$ & & \\
\hline Number of activities undertaken at UK coast & -1.042 & $(1.192)$ & & \\
\hline Number of activities undertaken at EMP area coast & $3.088 * * *$ & $(1.068)$ & & \\
\hline Quiz score & $12.636 * * *$ & $(1.253)$ & & \\
\hline Male (dummy) & $-2.274^{*}$ & $(1.200)$ & & \\
\hline University degree (dummy) & $2.960 * * *$ & $(1.080)$ & & \\
\hline Member of environmental organisation (dummy) & $4.064 *$ & $(2.108)$ & & \\
\hline Household income & $4.194 * * *$ & $(1.220)$ & & \\
\hline Household size & $-3.447 * *$ & $(1.570)$ & & \\
\hline Age 25-34 & $-12.047 * * *$ & $(3.314)$ & & \\
\hline Age 35-44 & -2.487 & $(2.157)$ & & \\
\hline Age 45-54 & $-5.001 * * *$ & $(1.837)$ & & \\
\hline Age 55-64 & $6.325 * *$ & $(2.486)$ & & \\
\hline Age 65-74 & $30.435 * * *$ & $(3.033)$ & & \\
\hline Age 75 and older & $28.445^{* * *}$ & $(3.113)$ & & \\
\hline LL at convergence & $-8,382$ & & & \\
\hline LL at constant(s) only & $-11,825$ & & & \\
\hline McFadden's pseudo- $\mathrm{R}^{2}$ & 0.291 & & & \\
\hline $\mathrm{BIC} / \mathrm{n}$ & 1.587 & & & \\
\hline Sobol draws & 2,000 & & & \\
\hline
\end{tabular}

Results show that respondents who live within 10 miles of the coast anywhere in England are more likely to prefer any of the change options as indicated by the significantly positive interaction effect.

\footnotetext{
${ }^{4}$ Note that this model uses 2,000 Sobol draws to simulate the log-likelihood. A model with 5,000 draws resulted in a slight smaller likelihood $(L L=-8,390)$ so the better performing model is presented here.
} 
The same is true for respondents with a university degree and those who are members of an environmental organisation. Male respondents, however, are less likely to support any of the change options. Looking at the role of age, the results suggest that comparably young groups (e.g. 25-34 and 45-54 years old) are less likely to value the proposed changes compared to the reference group of 18 to 24-olds, whereas older groups above 55 show a stronger support for the proposed changes. While household income is associated with stronger support for the change alternatives, household size is related to less support.

In terms of experience with the marine and coastal environments, the results show that the number activities respondents had ever engaged in at all UK coasts did not affect preferences, but that a count of the activities in the EMP area does in fact increase support for the proposed measures. All of these effects are independent from the levels of the attributes displayed on any particular choice option.

\section{Discussion}

By using a discrete choice experiment, this study demonstrated the applicability of stated preference valuation in the context of valuing change in the condition of offshore seabeds resulting from marine planning. The study shows that this approach can be employed even with components of natural capital and ecosystem services which are remote and unfamiliar to many people. The analysis produces a number of indicators of the robustness of the estimates of marginal WTP. The WTP estimates are robust to changes in the specification of the discrete choice model. Estimates from an MNL, a MXL model with normally distributed and correlated coefficients and a MXL with uncorrelated coefficients (see Table S.1 in the supplementary material) produce similar values.

Furthermore, a number of socio-demographic characteristics and other variables indicating the experience of respondents with the marine and coastal environment in the area are associated with preferences for the proposed changes in expected ways. Respondents who interact more with the area in question, as well as residents of coastal areas generally, show stronger preferences for the proposed measures for example. Respondents with higher household incomes, those with a university degree and members of environmental organisations were also more likely to prefer the proposed changes. The analysis further found that women tend to prefer one of the change options more strongly than men. This tendency for women to show greater environmental concern (which might be reflected in higher WTP) is also well-documented (Clements 2012, Hunter et al. 2004, Zelezny et al. 2000). The present study adds to a small but growing literature on the valuation of offshore marine ecosystems and natural capital (Torres and Hanley 2016). Comparison of the estimates of marginal WTP to similar estimates in that literature further highlights the robustness of values from this study. 
Using a sample of Scottish respondents, Jobstvogt et al. (2014) find an annual WTP of $£ 38.70$ for the protection of species diversity in Scottish marine waters. General species diversity is also valued by Börger et al. (2014b). They find a WTP for a $25 \%$ increase in species diversity in the UK section of the Dogger Bank, which is considerably smaller than the English EMP area, of $£ 7.76$ per year. The WTP estimates in the present study are much larger, with a WTP of $£ 49.10$ and $£ 68.70$ for changing the proportion of the EMP area with seabed in Good Environmental Status from a baseline of $35 \%$ to $50 \%$ and $70 \%$, respectively. Compared to previous valuations of similar changes, this may reflect both the fact that the seabed integrity supports general species diversity and that the EMP area is substantially larger than the Dogger Bank in the Börger et al. (2014b) study. The WTP figures in the present study also appear consistent with the estimates obtained by McVittie and Moran (2010) for an increase in biodiversity ( $\mathrm{f69.16}$ per household per year) and environmental benefits (£34.27) within Marine Conservation Zones. This study similarly employs a sample of respondents across England.

This research also found, perhaps surprisingly, that the general public in England values the restoration to Good Environmental Status of the seabed in the EMP area more than ensuring healthy population sizes for seabirds. This is at odds with the expectation that the general public are less concerned about components of the marine environment such as sedimentary seabeds which lack the obvious appeal of charismatic seabirds and marine mammals. The elicited values for changes to the condition of seabird populations are considered robust as the present study deliberately did not single out any seabird species which respondents might have regarded as 'charismatic' since it has previously been shown that providing the name of a species to be valued may lead to overestimated WTP figures (Jacobsen et al. 2008).

Furthermore, this study adds to the valuation exercise by Durán et al. (2015) to attempt to value the continuation of maritime way of life as a type of cultural ecosystem service. The results demonstrate that there are welfare losses amongst the general public when 'traditional' maritime sectors decline, and so consideration of the full economic implications of such decline should therefore potentially be widened to take account of this value change. This cultural aspect is, however, usually less important to respondents than environmental change. There is also no apparent correlation between valuations of this cultural ecosystem service and the proposed ecological changes in the area (regarding the seabed and populations of seabirds). The description of this attribute using job losses may be criticised as not capturing the gist of maritime heritage. This is a weakness in the valuation scenario. Yet, this just demonstrates the challenge of valuing certain cultural ecosystem services, such as maritime cultural heritage. Until better indicators of such ecosystem services become available, stated preference research will have to rely on short-hand indicators such as the one used in this study. 
The valuation study has a number of further weaknesses which need to be acknowledged. There may be concern about potential endogeneity of some of the respondent characteristics used to assess the validity of the choice responses in Table 8. The number of activities undertaken along the EMP area and wider English coast and arguably even the residential choice (to live within 10 miles of the coast) may be driven by the same underlying preference ordering for marine natural capital. Therefore, the inclusion of these variables as interaction terms with the ASC potentially leads to slightly biased coefficient estimates. While the use of integrated choice and latent variable models has been proposed in such situations, more recent research shows that this model type may not overcome the issue of endogeneity (Budzinski and Czajkowski 2018). In this situation, the results in Table 8 should be interpreted as correlations between these respondent characteristics and choice probabilities rather than as indicators of causal mechanisms.

In applying the values in the policy context, it must be noted that the study considers only subtidal sedimentary habitats (i.e. permanently submerged mud, sand, and gravel). Therefore, the values obtained are not applicable to rock habitats or to intertidal areas such as beaches or estuarine mudflats. Intertidal areas, especially popular sandy beaches, will have a much higher use component to their total economic value. Beaches and coastal areas have been the subject of greater research effort, and further examples of published valuations for these areas include Blakemore et al. (2008), Christie and Gibbons (2011), King (1995), Polyzos and Minetos (2007), Ropars-Collet et al. (2015), Voke et al. (2013), and Whitmarsh et al. (1999). Elicitation of the values held by scuba divers for subtidal habitats has shown that rocky and sedimentary areas have different values (Jobstvogt et al. 2014), demonstrating that it would not be applicable to transfer values from sedimentary to rocky habitats.

It is often the aspiration to use the values derived from stated preference studies in appraisal mechanisms such as cost-benefit analysis, for which the household or individual values as derived by the empirical research tend to be aggregated to allow a comparison with the total costs of a project or programme (Hanley and Barbier 2009). However, it is important to approach any such aggregation cautiously, particularly in terms of defining the political and economic jurisdiction of the 'market' for the good and the distinction between use and non-use values (Bateman et al. 2006). It can be particularly challenging to determine the appropriate number of beneficiaries of a particular ecological improvement (Hanley et al. 2003b). Choices made around aggregation can significantly affect value estimates and thus the outcome of cost-benefit analysis (Morrison 2000). Consequently, the present study does not present aggregated figures of the elicited values.

Nonetheless, the results provide a clear indication of the scale of non-use values that exist for natural capital assets for which this has hitherto not been known. These values can be used to support policy development and the implementation of management measures to achieve policy targets, or 
to examine trade-offs among services. Bioeconomic models are being developed for use in land management (Bateman et al 2013) that use valuation data to project trade-offs in values among wider ecosystem services. This modelling approach is gaining policy acceptance to the extent that it is referred to in the UK Government's 'Green Book' (HM Treasury 2018). In the marine environment spatial bioeconomic modelling of the use of offshore marine natural resources has been largely confined to fisheries management (Janßen et al. 2018), example models include RENTFISH (Salz et al. 2011, Simons et al. 2014), and SIMFISH (Bartelings et al. 2015). However, other modelling and planning tools such as MARXAN can incorporate values and costs as data layers (Rees et al. 2010, Henriques et al. 2017). There has also been some adaptation of valuation tools originally based on land-use or landcover type inputs, such as InVEST or ARIES, to determine ecosystem service flow in coastal zones and some offshore areas (Sharp et al. 2018, Arkema et al. 2015, Villa et al. 2014). Increasing the pool of valuation data, to which this study has added, broadens the application possibilities of bioeconomic modelling to develop options for management and financial incentives in the marine environment. Such projections would support policy and management, including spatial planning and licencing.

\section{Conclusions}

This study uses a discrete choice experiment survey around the benefits of improving the conditions of the seabed in England to demonstrate some of the challenges of valuing marine natural capital in a marine planning context. Values are derived for a set of marine goods and services which are impacted by management measures undertaken in the East of England Marine Plan area. This study thereby responds to calls for more valuation studies of marine and coastal natural capital (Bertram et al. 2014), addresses a gap in the valuation literature (Hooper et al. 2019b), and links directly to a policy need.

The fact that the study is conducted in the context of changes in management in marine plan areas in England demonstrates the applicability of stated preference valuation to support marine planning by allowing a quantification of the trade-offs between different outcomes of the planning process. The assessment of these trade-offs and related values constitutes are contribution to the valuation literature, particularly the attempt to value changes of maritime heritage as a type of cultural ecosystem service. The methodological and practical challenges that had to be overcome included: (1) Describing and clearly delineating impacts of environmental management measures on natural capital components to be valued in a highly spatially interconnected marine ecosystem; (2) the need to vary these attribute levels independently; (3) a feeling of remoteness and low level of knowledge of and familiarity with the survey area of the respondents. These challenges are specific to the marine environment and often complicate the use of stated preference valuation for marine planning, particularly in offshore areas. In this context, the present study showcases the importance of the 
following work steps to improve validity and robustness of stated preference valuation to support marine planning: (1) the involvement of interdisciplinary research teams; (2) rigorous survey development using focus groups and survey piloting; (3) tests of the relationship between respondent characteristics and differences in preferences for the proposed measures; (4) examination of the correlation structure of random preference weights.

Results show that the public in England attaches values to increases in the area of seabed in Good Environmental Status and increases in the number of seabird species with healthy population sizes. The public further anticipates welfare losses in case the number of seabird species with healthy populations declines. Further welfare losses are expected from the decline in maritime cultural heritage indicated by a loss of jobs in traditional maritime industries in the coastal areas under study. Values such as those elicited in this study can contribute to the evidence base in communicating the importance of sedimentary habitats, both in- and offshore.

\section{Acknowledgements}

This study was funded by the Department for Food, Environmental and Rural Affairs (Defra) (project ME5115) and also by the Natural Environment Research Council through the South West Partnership for the Environment and Economic Prosperity (SWEEP; grant NE/P011217/1).

\section{References}

Aanesen, M., Armstrong, C., Czaijkowski, M., Falk-Petersen, J., Hanley, N. and Navrud, S. (2015) Willingness to pay for unfamiliar public goods: Preserving cold-water coral in Norway. Ecological Economics 112, 53-67.

Abate, T.G., Börger, T., Aanesen, M., Falk-Andersson, J., Wyles, K.J. and Beaumont, N. (2020) Valuation of marine plastic pollution in the European Arctic: Applying an integrated choice and latent variable model to contingent valuation. Ecological Economics 169, 106521.

Arkema, K.K., Verutes, G.M., Wood, S.A., Clarke-Samuels, C., Rosado, S., Canto, M., Rosenthal, A., Ruckelshaus, M., Guannel, G., Toft, J. and Faries, J. (2015.) Embedding ecosystem services in coastal planning leads to better outcomes for people and nature. Proceedings of the National Academy of Sciences, 112(24), 7390-7395.

Austen, M.C., Anderson, P., Armstrong, C., Döring, R., Hynes, S., Levrel, H., Oinonen, S. and Ressurreição, A. (2019) Valuing Marine Ecosystems - Taking into account the value of ecosystem benefits in the Blue Economy. Coopman, J., Heymans, J., Kellett, P., Muñiz Piniella, A., French, V. and Alexander, B. (eds), European Marine Board, Ostend, Belgium. 
Báez, A. and Herrero, L.C. (2012) Using contingent valuation and cost-benefit analysis to design a policy for restoring cultural heritage. Journal of Cultural Heritage 13(3), 235-245.

Barbier, E.B. (2007) Valuing ecosystem services as productive inputs. Economic Policy 22(49), 177-229.

Barbier, E.B. (2012) Progress and Challenges in Valuing Coastal and Marine Ecosystem Services. Review of Environmental Economics and Policy 6(1), 1-19.

Barry, L., van Rensburg, T.M. and Hynes, S. (2011) Improving the recreational value of Ireland's coastal resources: A contingent behavioural application. Marine Policy 35(6), 764-771.

Bartelings, H., Hamon, K.G., Berkenhagen, J., Buisman, F.C. (2015) Bio-economic modelling for marine spatial planning application in North Sea shrimp and flatfish fisheries. Environmental Modelling \& Software, 74, 156-172.

Bateman, I.J., Day, B.H., Georgiou, S. and Lake, I. (2006) The aggregation of environmental benefit values: Welfare measures, distance decay and total WTP. Ecological Economics 60(2), 450-460.

Bertram, C., Dworak, T., Görlitz, S., Interwies, E. and Rehdanz, K. (2014) Cost-benefit analysis in the context of the EU Marine Strategy Framework Directive: The case of Germany. Marine Policy 43, 307-312.

Bateman, I., Harwood, A., Mace, G., Watson, R., Abson, D., Andrews, B., Binner, A., Crowe, A., Day, B, Dugdale, S., Fezzi, C., Foden, J., Haines-Young, R., Hulme, M., Kontoleon, A., Lovett, A., Munday, P., Pascual, U., Paterson, J., Perino, G., Sen, A., Siriwardena, G., van Soest D., and Termansen, M. (2013) Bringing ecosystem services into economic decision making: Land use in the UK. Science, 341(6141), 45-50.

Binet, T., Failler, P., Chavance, P.N. and Mayif, M.A. (2013) First international payment for marine ecosystem services: The case of the Banc d'Arguin National Park, Mauritania. Global Environmental Change 23(6), 1434-1443.

Bishop, R.C., Boyle, K.J., Carson, R.T., Chapman, D., Hanemann, W.M., Kanninen, B., Kopp, R.J., Krosnick, J.A., List, J., Meade, N., Paterson, R., Presser, S., Smith, V.K., Tourangeau, R., Welsh, M., Wooldridge, J.M., DeBell, M., Donovan, C., Konopka, M. and Scherer, N. (2017) Putting a value on injuries to natural assets: The BP oil spill. 356(6335), 253-254.

Blakemore, B., Burrell, M., and Jones, S. (2008) Beach users' aesthetic and economic evaluation of a "minor change" to the hard engineering coastal defences at Wiseman's Bridge, Pembrokeshire, Wales, WIT Transactions on Ecology and the Environment 108, 115-125.

Böhnke-Henrichs, A., Baulcomb, C., Koss, R., Hussain, S.S. and de Groot, R.S. (2013) Typology and indicators of ecosystem services for marine spatial planning and management. Journal of Environmental Management 130, 135-145. 
Börger, T. and Piwowarczyk, J. (2016) Assessing non-market benefits of seagrass restoration in the Gulf of Gdansk. Journal of Ocean and Coastal Economics 3, Article 1.

Börger, T., Beaumont, N.J., Pendleton, L., Boyle, K.J., Cooper, P., Fletcher, S., Haab, T., Hanemann, M., Hooper, T.L., Hussain, S.S., Portela, R., Stithou, M., Stockill, J., Taylor, T. and Austen, M.C. (2014a) Incorporating ecosystem services in marine planning: The role of valuation. Marine Policy 46(C), 161-170.

Börger, T., Böhnke-Henrichs, A., Hattam, C., Piwowarczyk, J., Schasfoort, F. and Austen, M.C. (2018) The role of interdisciplinary collaboration for stated preference methods to value marine environmental goods and ecosystem services. Estuarine, Coastal and Shelf Science 201, 140-151.

Börger, T., Hattam, C., Burdon, D., Atkins, J.P. and Austen, M.C. (2014b) Valuing conservation benefits of an offshore marine protected area. Ecological Economics 108(0), 229-241.

Börger, T., Hooper, T.L., Marcone, O., Rendon, O., Langmead, O., Rees, S. and Austen, M.C. (2019) Monetary valuation of subtidal sediments in England's Marine Plan Areas. Application of the natural capital approach to the marine environment to aid decision-making. Phase 2 Final Report. Report prepared for the Department for Environment Food and Rural Affairs (project code ME5115)

Börger, T., Hooper, T.L. and Austen, M.C. (2015) Valuation of ecological and amenity impacts of an offshore windfarm as a factor in marine planning. Environmental Science \& Policy 54, 126-133.

Brouwer, R., Brouwer, S., Eleveld, M.A., Verbraak, M., Wagtendonk, A.J. and van der Woerd, H.J. (2016) Public willingness to pay for alternative management regimes of remote marine protected areas in the North Sea. Marine Policy 68, 195-204.

Brouwer, R., Hadzhiyska, D., loakeimidis, C. and Ouderdorp, H. (2017) The social costs of marine litter along European coasts. Ocean \& Coastal Management 138(Supplement C), 38-49.

Burton, M., Jennings, S., Fragnol, L., Marre, J.-B., Parades, S., Pascoe, S., Rogers, A. and Yamazaki, S. (2015) The South-East Commonwealth Marine Reserves Network-public knowledge, perceptions and values survey. Marine Biodiversity NERP Theme 2: Supporting Management of Marine Biodiversity, Hobart, Tasmania, Australia.

Carr, L. and Mendelsohn, R. (2003) Valuing Coral Reefs: A Travel Cost Analysis of the Great Barrier Reef. AMBIO: A Journal of the Human Environment 32(5), 353-357.

Carson, R.T., Mitchell, R.C., Haneman, W.M., Kopp, R.J., Presser, S. and Ruud, P.A. (1992) A contingent valuation study of lost passive use values resulting from the Exxon Valdez oil spill, Anchorage.

Chae, D.-R., Wattage, P. and Pascoe, S. (2012) Recreational benefits from a marine protected area: A travel cost analysis of Lundy. Tourism Management 33(4), 971-977. 
ChoiceMetrics (2012) Ngene 1.1.1 User manual and reference guide.

Christie, M. and Gibbons, J. (2011) The effect of individual 'ability to choose' (scale heterogeneity) on the valuation of environmental goods. Ecological Economics 70(12), 2250-2257.

Claesson, S. (2011) The value and valuation of maritime cultural heritage. International Journal of Cultural Property, 18(1), 61-80.

Czajkowski, M., Vossler, C.A., Budziński, W., Wiśniewska, A. and Zawojska, E. (2017) Addressing empirical challenges related to the incentive compatibility of stated preferences methods. Journal of Economic Behavior \& Organization 142(Supplement C), 47-63.

Douvere, F. (2008) The importance of marine spatial planning in advancing ecosystem-based sea use management. Marine Policy 32(5), 762-771.

Douvere, F. and Ehler, C.N. (2009) New perspectives on sea use management: Initial findings from European experience with marine spatial planning. Journal of Environmental Management 90(1), 77-88.

Durán, R., Farizo, B.A. and Vázquez, M.X. (2015) Conservation of maritime cultural heritage: A discrete choice experiment in a European Atlantic Region. Marine Policy, 51, 356-365.

eftec (2014) Economic valuation of heritage. Final report for English Heritage.

European Commission (1992) Directive 92/43/EEC of the European Parliament and of the Council of 21 May 1992 on the conservation of natural habitats and wild fauna and flora (Habitats Directive). Official Journal of the European Union L206, 7-50.

European Commission (2008) Directive 2008/56/EC of the European Parliament and of the Council of 17 June 2008 establishing a framework for community action in the field of marine environmental policy (Marine Strategy Framework Directive). Official Journal of the European Union L164, 19-40.

European Commission (2016a) Good Environmental Status. Descriptor 6: Sea-floor Integrity. http://ec.europa.eu/environment/marine/good-environmental-status/descriptor-

6/index_en.htm Accessed 23 January 2019

European Commission (2016b) Good Environmental Status. Descriptor 1: Biodiversity. http://ec.europa.eu/environment/marine/good-environmental-status/descriptor-

1/index_en.htm Accessed 23 January 2019

European Commission \& European Environment Agency (2016) Report on phase 1 of the knowledge innovation project on an integrated system of natural capital and ecosystem services accounting in the EU (KIP-INCA Phase 1 report).

Foley, N.S., Kahui, V., Armstrong, C.W. and Van Rensburg, T.M. (2010) Estimating linkages between redfish and cold water coral on the Norwegian coast. Marine Resource Economics, 25(1), 105-120. 
Galparsoro, I., Borja, A. and Uyarra, M.C. (2014) Mapping ecosystem services provided by benthic habitats in the European North Atlantic Ocean. 1(23).

Haines-Young, R. and Potschin-Young, M., 2018. Revision of the common international classification for ecosystem services (CICES V5. 1): A policy brief. One Ecosystem, 3, e27108.

Hanley, N., Bell, D. and Alvarez-Farizo, B. (2003a) Valuing the Benefits of Coastal Water Quality Improvements Using Contingent and Real Behaviour. Environmental and Resource Economics 24(3), 273-285.

Hanley, N., Schläpfer, F. and Spurgeon, J. (2003b) Aggregating the benefits of environmental improvements: distance-decay functions for use and non-use values. Journal of Environmental Management 68(3), 297-304.

Hanley, N., Hynes, S., Patterson, D. and Jobstvogt, N. (2015) Economic valuation of marine and coastal ecosystems: Is it currently fit for purpose? Journal of Ocean and Coastal Economics 2.

Hattam, C., Atkins, J.P., Beaumont, N., Börger, T., Böhnke-Henrichs, A., Burdon, D., de Groot, R., Hoefnagel, E., Nunes, P.A.L.D., Piwowarczyk, J., Sastre, S. and Austen, M.C. (2015) Marine ecosystem services: Linking indicators to their classification. Ecological Indicators 49(0), 61-75.

Henriques, N.S., Monteiro, P., Bentes, L., Oliveira, F., Afonso, C.M. and Gonçalves, J.M. (2017) Marxan as a zoning tool for development and economic purposed areas-Aquaculture Management Areas (AMAs). Ocean \& Coastal Management, 141, 90-97.

HM Government (2011) The natural choice: Securing the value of nature. HM Government Natural Environment White Paper. Presented to Parliament by the Secretary of State for Environment, Food and Rural Affairs by Command of Her Majesty. Available at: https://www.gov.uk/government/publications/the-natural-choice-securing-the-value-of-nature

HM Government (2011) The natural choice: Securing the value of nature, Her Majesty's Stationery Office, London.

HM Government (2014) East inshore and east offshore marine plans. Marine Management Organisation. Available at: https://www.gov.uk/government/publications/east-inshore-and-eastoffshore-marine-plans

HM Government (2018) A green future: Our 25 year plan to improve the environment. London: Department for the Environment Food and Rural Affairs, London. Available at: https://www.gov.uk/government/publications/25-year-environment-plan

HM Treasury (2018) The Green Book: Central Government guidance on appraisal and evaluation, HM Treasury, London. Available at: https://assets.publishing.service.gov.uk/government/uploads/ system/uploads/attachment data/file/685903/The Green Book.pdf 
Hooper, T., Börger, T., Langmead, O., Marcone, O., Rees, S.E., Rendon, O., Beaumont, N., Attrill, M.J. and Austen, M. (2019a) Applying the natural capital approach to decision making for the marine environment. Ecosystem Services, 38, 100947.

Hooper, T., Ashley, M., Börger, T., Langmead, O., Marcone, O., Rees, S., Rendon, O., Beaumont, N., Attrill, M. and Austen, M. (2019b) Application of the natural capital approach to the marine environment to aid decision-making. Phase 1 Final Report, prepared for the Department for Environment Food and Rural Affairs (project code ME5115). Available at: http://randd.defra.gov.uk/Document.aspx?Document=14440 FinalreportPhase1.pdf

Hooper, T., Beaumont, N., Griffiths, C., Langmead, O. and Somerfield, P.J. (2017) Assessing the sensitivity of ecosystem services to changing pressures. Ecosystem Services 24, 160-169.

Hynes, S., Tinch, D. and Hanley, N. (2013) Valuing improvements to coastal waters using choice experiments: An application to revisions of the EU Bathing Waters Directive. Marine Policy 40(0), 137-144.

Jacobsen, J.B., Boiesen, J.H., Thorsen, B.J. and Strange, N. (2008) What's in a name? The use of quantitative measures versus 'Iconised' species when valuing biodiversity. Environmental and Resource Economics 39(3), 247-263.

Janßen, H., Bastardie, F., Eero, M., Hamon, K.G., Hinrichsen, H.-H., Marchal, P., Nielsen, J.R., Le Pape, O., Schulze, T., Simons, S., Teal, L.R., Tidd, A. (2018) Integration of fisheries into marine spatial planning: Quo Vadis? Estuarine, Coastal and 7Shelf Science 201, 105-113.

Jefferson, R.L., Bailey, I., Laffoley, D.d.A., Richards, J.P. and Attrill, M.J. (2014) Public perceptions of the UK marine environment. Marine Policy 43, 327-337.

Jobstvogt, N., Hanley, N., Hynes, S., Kenter, J. and Witte, U. (2014) Twenty thousand sterling under the sea: Estimating the value of protecting deep-sea biodiversity. Ecological Economics 97(0), 1019.

Johnston, R.J., Boyle, K.J., Adamowicz, W., Bennett, J., Brouwer, R., Cameron, T.A., Hanemann, W.M., Hanley, N., Ryan, M., Scarpa, R., Tourangeau, R. and Vossler, C.A. (2017) Contemporary Guidance for Stated Preference Studies. Journal of the Association of Environmental and Resource Economists 4(2), 319-405.

King, O. H. (1995) Estimating the value of marine resources: a marine recreation case. Ocean \& Coastal Management, 27(1), 129-141.

Kling, C.L., Phaneuf, D.J. and Zhao, J. (2012) From Exxon to BP: Has Some Number Become Better Than No Number? Journal of Economic Perspectives 26(4), 3-26. 
Krueger, A.D., Parsons, G.R. and Firestone, J. (2011) Valuing the Visual Disamenity of Offshore Wind Power Projects at Varying Distances from the Shore: An Application on the Delaware Shoreline Land Economics 87(2), 268-283.

Ladenburg, J. and Dubgaard, A. (2007) Willingness to pay for reduced visual disamenities from offshore wind farms in Denmark. Energy Policy 35(8), 4059-4071.

LaRiviere, J., Czajkowski, M., Hanley, N., Aanesen, M., Falk-Petersen, J. and Tinch, D. (2014) The value of familiarity: Effects of knowledge and objective signals on willingness to pay for a public good. Journal of Environmental Economics and Management 68(2), 376-389.

Lau, W.W.Y. (2013) Beyond carbon: Conceptualizing payments for ecosystem services in blue forests on carbon and other marine and coastal ecosystem services. Ocean \& Coastal Management 83, 514.

Laurans, Y., Rankovic, A., Bille, R., Pirard, R. and Mermet, L. (2013) Use of ecosystem services economic valuation for decision making: Questioning a literature blindspot. Journal of Environmental Management 119, 208-219.

Lazo, J.K., McClelland, G.H. and Schulze, W.D. (1997) Economic theory and psychology of non-use values. Land Economics, pp.358-371.

León, C.J., Araña, J.E., Hanemann, W.M. and Riera, P. (2014) Heterogeneity and emotions in the valuation of non-use damages caused by oil spills. Ecological Economics 97, 129-139.

Liquete, C., Piroddi, C., Drakou, E.G., Gurney, L., Katsanevakis, S., Charef, A. and Egoh, B. (2013) Current Status and Future Prospects for the Assessment of Marine and Coastal Ecosystem Services: A Systematic Review. PLOS ONE 8(7).

Loureiro, M.L., Loomis, J.B. and Xosé Vázquez, M. (2009) Economic valuation of environmental damages due to the Prestige oil spill in Spain Environmental and Resource Economics 44(4), 537553.

Maes, J., Teller, A., Erhard, M., Liquete, C., Braat, L., Berry, P., Egoh, B., Puydarrieux, P., Fiorina, C., Santos-Martín, F., Paracchini, M., Keune, H., Wittmer, H., Hauck, J., Fiala, I., Verburg, P., Condé, S., Schägner, J., San-Miguel-Ayanz, J., Estreguil, C., Ostermann, O., Barredo, J., Pereira, H., Stott, A., Laporte, V., Meiner, A., Olah, B., Royo Gelabert, E., Spyropoulou, R., Petersen, J.-E., Maguire, C., Zal, N., Achilleos, E., Rubin, A., Ledoux, L., Murphy, P., Fritz, M., Brown, C., Raes, C., Jacobs, S., Raquez, P., Vandewalle, M., Connor, D. and Bidoglio, G. (2013) Mapping and Assessment of Ecosystems and their Services - An analytical framework for ecosystem assessments under action 5 of the EU biodiversity strategy to 2020, Publications office of the European Union. 
Marine Management Organisation (2018) UK fisheries statistics 2017. Marine Management Organisation, London.

McBreen, F., Askew, N., Cameron, A., Connor, D., Ellwood, H. and Carter, A. (2011) UKSeaMap 2010:

Predictive mapping of seabed habitats in UK waters, Joint Nature Conservation Committee, Peterborhough.

McFadden, D. (1974) Conditional logit analysis of qualitative choice behavior. In: Zarembka, P. (ed), Frontiers in econometrics, economic theory and mathematical economics, 105-142, Academic Press, New York.

McVittie, A. and Moran, D. (2010) Valuing the non-use benefits of marine conservation zones: An application to the UK Marine Bill. Ecological Economics 70(2), 413-424.

MEA (2005) Millennium Ecosystem Assessment. Ecosystems and human well-being: A framework for assessment, Island Press, Washington DC.

Morrison, M. (2000) Aggregation biases in stated preference studies. Australian Economic Papers $39(2), 215-230$.

Natural Capital Committee (2015) The state of natural capital. protecting and improving natural capital for prosperity and well-being. Third report to the Economic Affairs Committee. Department for Environment Food and Rural Affairs. https://www.gov.uk/government/publications/naturalcapital-committees-third-state-of-natural-capital-report

Navrud, S., Lindhjem, H. and Magnussen, K. (2016) Handbook on the Economics and Management for Sustainable Oceans. Nunes, P.A.L.D., Kumar, P., Svensson, L.E. and Markandya, A. (eds), Edward Elgar, Cheltenham.

NEA, U. (2011) UK National Ecosystem Assessment: Synthesis of Key Findings, UNEP-WCMC, Cambridge.

NEA-FO, U. (2014) UK National Ecosystem Assessment Follow-on. Synthesis of the key findings, UNEPWCMC, LWEC, Cambridge.

Needham, K. and Hanley, N. (2019) Valuing a managed realignment scheme: What are the drivers of public willingness to pay? Ocean \& Coastal Management 170, 29-39.

Nieminen, E., Ahtiainen, H., Lagerkvist, C.-J. and Oinonen, S. (2019) The economic benefits of achieving Good Environmental Status in the Finnish marine waters of the Baltic Sea. Marine Policy 99, 181189.

Norton, D. and Hynes, S. (2014) Valuing the non-market benefits arising from the implementation of the EU Marine Strategy Framework Directive. Ecosystem Services 10(0), 84-96. 
OSPAR (2017) Intermediate Assessment 2017. Extent of Physical Damage to Predominant and Special Habitats. Available at: https://oap.ospar.org/en/ospar-assessments/intermediate-assessment2017/biodiversity-status/habitats/extent-physical-damage-predominant-and-special-habitats/ (accessed 14 January 2019).

Pakalniete, K., Aigars, J., Czajkowski, M., Strake, S., Zawojska, E. and Hanley, N. (2017) Understanding the distribution of economic benefits from improving coastal and marine ecosystems. Science of The Total Environment 584, 29-40.

Paltriguera, L., Ferrini, S., Luisetti, T. and Turner, R.K. (2018) An analysis and valuation of postdesignation management aimed at maximising recreational benefits in coastal Marine Protected Areas. Ecological Economics 148, 121-130.

Peters, H. and Hawkins, J.P. (2009) Access to marine parks: A comparative study in willingness to pay. Ocean \& Coastal Management 52(3), 219-228.

Polyzos, S. and Minetos, D. (2007) Valuing environmental resources in the context of flood and coastal defence project appraisal: A case-study of Poole Borough Council seafront in the UK. Management of Environmental Quality: An International Journal, 18(6), 684-710.

Rees, S.E., Rodwell, L.D., Attrill, M.J., Austen, M.C. and Mangi, S.C. (2010) The value of marine biodiversity to the leisure and recreation industry and its application to marine spatial planning. Marine Policy, 34(5), 868-875.

Revelt, D. and Train, K. (1998) Mixed Logit with Repeated Choices: Households' Choices of Appliance Efficiency Level. Review of Economics and Statistics 80(4), 647-657.

Rodrigues, L.C., van den Bergh, J.J.M., Loureiro, M.L., Nunes, P.L.D. and Rossi, S. (2015) The Cost of Mediterranean Sea Warming and Acidification: A Choice Experiment Among Scuba Divers at Medes Islands, Spain. Environmental and Resource Economics, 1-23.

Rolfe, J. and Gregg, D. (2012) Valuing beach recreation across a regional area: The Great Barrier Reef in Australia. Ocean \& Coastal Management 69(0), 282-290.

Rolfe, J. and Windle, J. (2012) Distance decay functions for iconic assets: Assessing national values to protect the health of the Great Barrier Reef in Australia. Environmental and Resource Economics 53(3), 347-365.

Ropars-Collet, C., Leplat, M., Le Goffe, P. and Lesueur, M. (2015) Commercial Fishery as an Asset for Recreational Demand on the Coastline: Evidence from a Choice Experiment in France, UnitedKingdom and Belgium. Conference Paper No. 9. EAFE 2015 XXII Conference of the European Association of Fisheries Economists. 
Rose, C., Dade, P. and Scott, J. (2008) Qualitative and quantitative research into public engangement with the undersea landscape in England, Natural England, Sheffield.

Sagebiel, J., Schwartz, C., Rhozyel, M., Rajmis, S. and Hirschfeld, J. (2016) Economic valuation of Baltic marine ecosystem services: blind spots and limited consistency. ICES Journal of Marine Science: Journal du Conseil 73(4), 991-1003.

Salomidi, M., Katsanevakis, S., Borja, Á., Braeckman, U., Damalas, D., Galparsoro, I., Mifsud, R., Mirto, S., Pascual, M. and Pipitone, C.J.M.M.S. (2012) Assessment of goods and services, vulnerability, and conservation status of European seabed biotopes: a stepping stone towards ecosystem-based marine spatial management. Mediterranean Marine Science 13(1), 49-88.

Salz, P., Buisman, E., Soma, K., Frost, H., Accadia, P. and Prellezo, R. (2011) FISHRENT: Bioeconomic simulation and optimisation model for fisheries. In: LEI Report 2011-024, LEI Wageningen UR, The Hague.

Sandorf, E.D., Aanesen, M. and Navrud, S. (2016) Valuing unfamiliar and complex environmental goods: A comparison of valuation workshops and internet panel surveys with videos. Ecological Economics 129, 50-61.

Silberman, J. and Klock, M. (1988) The recreation benefits of beach renourishment. Ocean and Shoreline Management 11(1), 73-90.

Silberman, J., Gerlowski, D.A. and Williams, N.A. (1992) Estimating Existence Value for Users and Nonusers of New Jersey Beaches. Land Economics 68(2), 225-236.

Simons, S.L., Bartelings, H., Hamon, K.G., Kempf, A.J., Döring, R. and Temming, A. (2014) Integrating stochastic age-structured population dynamics into complex fisheries economic models for management evaluations: the North Sea saithe fishery as a case study. ICES Journal of Marine Science, 71(7), 1638-1652.

Sharp, R., Tallis, H.T., Ricketts, T., Guerry, A.D., Wood, S.A., Chaplin-Kramer, R., Nelson, E., Ennaanay, D., Wolny, S. and Olwero, N. (2018) InVEST 3.5.0. User's Guide. The Natural Capital Project. Stanford University, University of Minnesota, The Nature Conservancy, World Wildlife Fund.

Spalding, M.J. (2016) The new blue economy: The future of sustainability. Journal of Ocean and Coastal Economics 2(2).

Steel, B.S., Smith, C., Opsommer, L., Curiel, S. and Warner-Steel, R. (2005) Public ocean literacy in the United States. Ocean \& Coastal Management 48(2), 97-114.

Stefanski, S.F. and Shimshack, J.P. (2016) Valuing marine biodiversity in the Gulf of Mexico: Evidence from the proposed boundary expansion of the Flower Garden Banks National Marine Sanctuary. Marine Resource Economics 31(2), 211-232. 
TEEB (2010) The Economics of Ecosystems and Biodiversity: Ecological and Economic Foundations, Earthscan, London and Washington.

Thrush, S.F. and Dayton, P.K. (2002) Disturbance to Marine Benthic Habitats by Trawling and Dredging: Implications for Marine Biodiversity. 33(1), 449-473.

Tillin, H.M., Langmead, O., Hodgson, B., Luff, A., Rees, S., Hooper, T. and Frost, M. (2019) Feasibility study for a marine natural capital asset index for Scotland.

Torres, C. and Hanley, N. (2016) Economic valuation of coastal and marine ecosystem services in the 21st century: An overview from a management perspective, University of St Andrews, St Andrews, UK.

Train, K. and Weeks, M. (2005) Application of simulation methods in environmental and resource economics. Scarpa, R. and Alberini, A. (eds), pp. 1-16, Springer, Dordrecht.

Tuhkanen, H., Piirsalu, E., Nõmmann, T., Karlõševa, A., Nõmmann, S., Czajkowski, M. and Hanley, N. (2016) Valuing the benefits of improved marine environmental quality under multiple stressors. Science of The Total Environment 551-552, 367-375.

Villa, F., Bagstad, K.J., Voigt, B., Johnson, G.W., Portela, R., Honzák, M. and Batker, D. (2014) A methodology for adaptable and robust ecosystem services assessment. PloS one, 9(3), e91001.

Voke, M., Fairley, I., Willis, M. and Masters, I. (2013) Economic evaluation of the recreational value of the coastal environment in a marine renewables deployment area. Ocean \& Coastal Management 78(0), 77-87.

Wattage, P., Glenn, H., Mardle, S., Van Rensburg, T., Grehan, A. and Foley, N. (2011) Economic value of conserving deep-sea corals in Irish waters: A choice experiment study on marine protected areas. Fisheries Research 107(1-3), 59-67.

Westerberg, V., Jacobsen, J.B. and Lifran, R. (2013) The case for offshore wind farms, artificial reefs and sustainable tourism in the French mediterranean. Tourism Management 34(0), 172-183.

Whitehead, J.C. and Finney, S.S., 2003. Willingness to pay for submerged maritime cultural resources. Journal of Cultural Economics, 27(3-4), 231-240.

Whitmarsh, D., Northen, J. and Jaffry, S. (1999) Recreational benefits of coastal protection: a case study. Marine Policy 23(4-5), 453-463.

Wielgus, J., Chadwick-Furman, N.E., Zeitouni, N. and Shechter, M. (2003) Effects of coral reef attribute damage on recreational welfare. Marine Resource Economics 18, 225-237.

Xuan, B.B., Sandorf, E.D. and Aanesen, M. (2017) Informing management strategies for a reserve: Results from a discrete choice experiment survey. Ocean \& Coastal Management 145(Supplement C), 35-43. 


\section{Online supplementary material}

Table S.1. MXL models in WTP-space (with uncorrelated random coefficients)

\begin{tabular}{|c|c|c|c|c|}
\hline & \multicolumn{4}{|c|}{ MXL } \\
\hline & Coef. & s.e. & SD & s.e. \\
\hline$\overline{A S C}$ & $24.032 * * *$ & $(6.344)$ & $145.434 * * *$ & (7.661) \\
\hline SEABED50 & $41.710 * * *$ & (4.069) & 1.227 & (3.805) \\
\hline SEABED70 & $64.496 * * *$ & (4.613) & $33.962 * * *$ & (3.928) \\
\hline JOBS25 & $-20.694 * * *$ & $(2.435)$ & 0.538 & (4.867) \\
\hline JOBS50 & $-45.680 * * *$ & $(3.360)$ & $54.630 * * *$ & $(4.236)$ \\
\hline BIRDS40 & $-36.913 * * *$ & (3.601) & $34.882 * * *$ & (5.593) \\
\hline BIRDS75 & $25.388 * * *$ & $(2.792)$ & 2.122 & $(4.254)$ \\
\hline LL at convergence & $-8,636$ & & & \\
\hline LL at constant(s) only & $-11,825$ & & & \\
\hline McFadden's pseudo- $\mathrm{R}^{2}$ & 0.270 & & & \\
\hline $\mathrm{BIC} / \mathrm{n}$ & 1.597 & & & \\
\hline Sobol draws & 5,000 & & & \\
\hline
\end{tabular}

Notes: $\mathrm{N}=1,212$ respondents; 10,908 choices. s.e. - standard error. ${ }^{* * *}$ indicate significance at the $1 \%$-level of confidence. In the MXL model, all coefficients are assumed to be normally distributed and correlated except for the cost coefficient which is assumed to be log-normally distributed. 